Валентина Питулић

Филозофски факултет

Универзитета у Приштини

са привременим седиштем

у Косовској Митровици

e-mail: valentina.pitulic@pr.ac.rs

https://doi.org/10.18485/ai_san_o_gradu.2020.ch2

821.163.41.09:398

Оригинални научни рад

\title{
НЕБЕСКИ ГРАД У СРПСКОЈ УСМЕНОЈ ТРАДИЦИЈИ*
}

У раду се бавимо небеским градом који се у усменој традицији Срба најчешће гради у пределу под небесима, односно на грану од облака. Показаћемо на који начин је град, који граде митолошка бића, временом добио хришћанско обележје, где се црква гради сама од себе. У песмама о градњи града на облаку обезбеђује се плодност. Присуство женског принципа (вила, девојка, Огњена Марија) указује на порекло песме, која представља неку врсту градитељске химне. Присуство небеског града и у прозним жанровима указује на његову комплексност, која захтева ново читање, са циљем праћења генезе градње града на облаку у огледалу варијаната различитих етнопсихолошких заједница.

Кључне речи: град, небо, облак, вила, девојка, врата, злато, црква.

* Рад је рађен у оквиру пројекта Српско усмено стваралаштво у интеркултурном коду (бр.178011) Института за књижевност и уметност Београд, који финансира Министарство просвете, науке и технолошког развоја Србије. 
У традицији многих народа изражена је потреба за хомогенизацијом нехомогених простора. У веровањима древних цивилизација постоји представа о простору који има пукотине, који није дефинисан и одређен. Прво човеково религиозно искуство почива на веровању да простор није одређен већ чека да буде обликован и стављен у одређену форму. Тражен је ослонац који ће бити она тачка на којој ће почивати свет. Тражење тачке ослонца, значило је приступити чину стварања, али тако да тај чин мора бити усмерен у неком правцу, осносно у правцу дефинисања и маркирања светог простора који, како би рекао Мирча Елијаде подразумева неку хијерофанију, излив светога, чиме се извесна територија одваја из космичке средине која је окружује, чинећи је квалитативно различитом (Елијаде 2003: 79).

У словенској традицији небо представља аналогију латинском nebes, што има значење облак. Примарно значење термина небо у словенском контексту значило је облачно небо које је спојено са земљом, што одговара санскритском nabhas што значи сnаjamu. У српској народној традицији небо је представљено као спој са планином, која је на крају света. На основу реконструкције древног веровања постоји представа о горњем, ведром небу, на којем је врховни Бог, и доњем небу, на којем су активне атмосферске промене, где доминирају громови. Код неких народа, уз симболично значење броја девет и седам, постоји не једно, већ седам или девет небеса (СМР 1970: 222).

У колективном наслеђу Срба небески простор испуњен је небеским телима, која су представљена као жива бића. Веровање у вишедимензионално значење Сунца, Месеца, звезда и других небеских тела, представља митолошку слику у којој Космос 
има обележје живе твари, у којој свако небеско тело има своју одређену улогу. Занимљиво је да је народ замишљао небо не као равно, већ испупчено, али је имао представу и о његовј материјалној атрибуцији. Наиме, Словени су имали представу о двоструком небу, доњем и горњем, која су имала различите карактеристике. ${ }^{1}$ У том горњем пределу неба у народној космогонији све је дефинисано. Сунце је често представљено као млад јунак и његов култ је у српској традицији веома развијен (Чајкановић 1994: 321-335). Његово дефинисање и давање атрибута покретног тела везује се и за смену дана и ноћи. У српској народној традицији осећа се и митраистички утицај, где видимо непобедивост сунца, а у римским провинцијама у којима су живели Срби налазимо и на топониме („Сунчани град“) који указују на остатке овог веровања (Чајкановић 1994: 334). На основу топонима „Сунчани град“ можемо претпоставити да

1 Пошто су ова два неба по својој природи тако различита, није ништа необично да материја од које су начињена није иста за оба. Сјајно небо могло се замишљати као да је од углачаног камена, доцније и стакла или сребра. Оно је чврсто, тешко и непроменљиво, на њему се налази бог који влада светом, по њему иду Сунце, Месец и звезде, оне небеске појаве које показују правилност и сталност у своме кретању и светлости. Ово горње небо бива с времена на време, доста често, прекривено као неким застором. То је доње небо. Оно нема ни чврстине ни сталности горњега неба, већ се, напротив, често мења, прекрива Земљу као неки шатор који се потом лако раставља, цепа, баш као да је од неке слабе и лаке материје, коже или платна, На овоме доњем небу одигравају се честе и неправилне промене, понекад страшне, појављују се муње, громови, облаци, ветрови, то је небо вила, али и других атропоморфизованих атмосферских појава.“ Ненад Ђ. Јанковић, Астрономија у преданима, обичајима и умотворинама Срба, Српска академија наука, Београд, 1951, стр. $30)$. 
је у древној прошлости постојао некакав простор у којем је градитељску моћ имало управо Сунце, које је добило божанске атрибуте. Веселин Чајкановић тврди да је Месец у небеском простору имао везе са атрибутима ноћи и доюег света (Чајкановић 1994: 336). У народној традицији Месец добија и атрибуте младожење.

У песми „Женидба сјајнога месеца“ из Вукове збирке, која, како би рекао Миодраг Павловић делује мало схематски (Павловић 1993: 18) звезда Даница, како каква древна градитељка, уређује Космос тако што иницира небеску свадбу, која је предуслов сваког стварања. У највишим пределима неба догађа се космичка свадба у којој главну реч има звезда Даница. Космос још увек није уређен, а у небеском простору доминира звезда Даница која се фали да ће оженити сјајнога Мјесеца. Сам чин женидбе, односно успостављања космичке свадбе, можемо посматрати као почетак градње, у простору где још увек ништа није дефинисано. Христијанизација песме, у којој су сватови хришћански светитељи, у којој муња, невеста, дели дарове, представља степен лаганог силаска из далеких простора неба, где обитавају само Сунце, Месец и звезде, у ниже простоpe, где владају муње и громови. Невеста, коју представља муња, на неки начин преузима будућу улогу градитељке, односно женског принципа. ${ }^{2}$ Уређење

2 „Жена је, дакле, мистички солидарисана са Земљом, рађање се представља као људска варијанта магијске плодности. Сва религиозна искуства, која су у вези с плодношћу и рођењем, имају космичку структуру. Сакралност жене зависи од светости Земље. Женска плодност има космички модел: Модел Терра Матер, универзалне Родитељице." Мирча Елијаде, Свето и профано, Издавачка књижарница Зорана Стојановића, Сремски Карловци-Нови Сад, 2003, стр. 167. 
космоса и стварање календара, представља лагани силазак у пределе где још увек не назиремо човека и његово градитељску активност. Актери космичке свадбе, звезда Даница, Месец, муња, и светитељи припремају терен за тихо насељавање нижих небеских предела, који је у другом делу песме потпуно христијанизован.

Силазак у небеску сферу, која је у традицији многих народа представљала доњи простор неба, отвара могућност дубљег понирања у смисао стварања, односно грађења. У српској народној традицији напуштају се простори у којима звезда Даница управља Космосом и долази се у оне пределе у којима се назиру облаци. ${ }^{3}$ Они у традиционалној култури Срба представљају место које је маркирано као простор нове хомогенизације, односно место где почиње чин стварања који се на неки начин одваја од оног које припада вишим космичким сферама. У варијантама песама о зидању града на облаку мар-

3 „У нашој народној митологији облак се јавља најчешће као место боравка разних демона али и божанстава, а некад је, вероватно, и сам представљао божанство. Добро је познато да народна машта често замишља обитавалиште вила у облацима. Осим тога, по веровањима, градобитне облаке су предводиле але, душе самоубица или утопљеника, против којих се боре змајеви или здухачи. По Чајкановићу, сам облак је представљао божанство или је у њему присутан врховни бог. Дабог, у време некадашњих његових празника који су замењени Божићем и Ђурђевданом. Исто тако, он види Дабогову епифанију у облаку и у веровањима везаним за сезону некадашњих Дабогових празника: „На Крстовдан народ верује да ће у потесу добро родити она страна на коју путују облаци, а неће родити она с које путују облаци“; веровало се исто тако да ће она страна у потесу најбоље родити с које се на Видовдан увече појаве облаци. Плодност би требало да буде изазвана присуством божанства у облаку“. (СМР: 1970: 227) 
кираће се и простор под небеса, који налазимо у народним песмама са Косова и Метохије. ${ }^{4}$

Како је религиозни човек имао потребу за светим, тежио је да хомогенизује простор, односно да пронађе тачку ослонца. У традицији древних цивилизација човек тачку ослонца није могао да пронађе сам, већ је, како наводи Мирча Елијаде, морао да потражи некакав знак који ће да га упути на простор који је погодан за градњу. ${ }^{5}$ Човек није имао моћ да сазна тајне гради-

4 Град градила бела вила, Ни на небо ни на земљу, Но градила под небеса; Прва врата од дуката, Друга врата од позлата, Tрећа врата од бисера. Што су врата од дуката, То ми вила сина жени, Што су врата од позлата То ми вила ћеркудава Шіто су врата од бисера, То ми вила сама седи. Српске народне умотворине са Косова из рукописа Дене Дебельковића, књига прва, лирске и епске народне песме, приредио Владимир Бован, Академија наука и уметности Косова, Приштина, 1984, стр. 46.

5 „Уколико се никакав знак не манифестује у околини, онда се он изазива. Упражњава се, на пример, нека врста evocation помоћу животиња: оне показују које је место погодно да се на њему подигне светилиште или насеобина. Реч је углавном о призивању светих снага или слика, чији је непосредни циљ сналажење у хомогености простора. Тражи се неки знак да би се укинула напетост између релативитета и неспокојства што произлази из дезорјентације, све у свему да би се нашла једна апсолутна тачка ослониа. На пример, гони се нека звер, и на месту на којем је достигну и убију подиже се светилиште, или пак, пушта се на слободу нека домаћа животиња - бик, на пример и после неколико дана креће се у потрагу за њим. На месту на којем се пронађе, бива жртвована, подиже се жртвеник и гради село око њега. У свим тим случајевима животиње су те које 
тељства. Тај чин је био део неког мистичног ритуала, који је, како наводи Мирча Елијаде ефикасан (је) само утолико уколико репродукује дело богова (Елијаде 2003: 81). Пратећи усмено наслеђе Срба запажамо да је тај први чин градње, односно иницирање уређења Космоса, преко мотива космичке свадбе, припадао звезди Даници (Чајкановић 1994: 339-344) док ће она касније бити трансформисана и њу ће заменити вила. Како се из сфере космогонијског, градња спуштала према човековом уређењу свог дома, ни он неће моћи да буде саграђен док се градитељска моћ из сфере небеског ни на небу ни на земљу, не спусти на предео земаљског.

Позиционирање града, који се гради на грану од облака, почетак је уређења не само небеског простора већ ће усмено казивање кренути у правцу спуштања небеског града из облака на сакрализовани простор земље. Градитељка града на облаку је, по правилима тајне градитељства, из сфере која не припада човеку. Вила ${ }^{6}$ из тајних сфера несазнатног гради град на грану од облака. Прозрачност облака, који мења свој облик, требало би да обезбеди статичност, односно да допусти градњу. У песми у којој вила гради град фокусиран је простор, грана од облака. Одређена је градитељка, бјела вила (није ли ово почетак градње града који ће бити означен

откривају светост места: људи, дакле, немају ту способност да бирају насеобину - они само траже и откривају је помоћу тајанствених знакова“. Мирча Елијаде, Свето и пробано, Издавачка књижарница Зорана Стојановића, Сремски Карловци-Нови Сад, 2002, стр. 80.

6 „Веровало се да виле живе у рекама, потоцима и језерима, затим у столетним шумама, под земљом или чак у облацима. У народу су их често и називали по месту боравка: планинкиње, нагоркиње, подгоркиње, језеркиње, бродарице, приморкиње, облакиње итд“. Душан Бандић, Народна религија Срба у 100 појмова, Нолит, Београд, 1991, стр. 150. 
формулом бели град). Ако се зауставимо на јаснијој позицији где се гради град, а то је грана од облака, могли бисмо да претпоставимо да је у песми већ маркирано чудесно дрво. Оно је у култури многих народа успело да изрази све оно ито религиозни човек сматра стварним и светим у правом смислу речи (Елијаде 2003: 171) као оса света, која се лагано настањује. Град на грани од облака није посебно дефинисан. Он нема облик, а прво његово обележје су троја врата. Сва тајна чудесног града на облаку дефинисана је вратима, односно бројем три, који има посебно значење. Град је помало етеричан и нестваран. Како свака градња, да би се одржала, захтева извесну жртву, вила, која има тајне моћи, сама влада градњом. Жртва као да није потребна, јер она припада доњим сферама. Да би човек саградио град мора да принесе жртву (као у песми „Зидање Скадра“) и то по строго одређеним правилима. Овај небескии град никог и ничим не условљава. Све се догађа у пределима владавине небеских сила, којима припада и вила. Граду је потребна нека врста стабилности која је апострофирана бројем три, односно градњом троја врата. Три ${ }^{7}$ као стабилан број, први је обрис града који настаје у етеричном простору. Врата ${ }^{8}$ асоцирају на улазак у

7 „TRI. Mnogostrukost, tvorna moć; rast; unapredno kretanje što savlađuje dualnost; izraz, sinteza. „Tri je prvi broj kojem je dodeljena reč „sve“ i „trijada je broj celine, pošto sadrži početak, sredinu i kraj“ (Aristotel). „Moć broja tri“ je univerzalna i ono predstavlja trojnu prirodu sveta kao neba, zemlje i vode; ono je čovek kao telo, duša i duh; rodjenje, život i smrt; početak, sredina, kraj; Prošlost, sadašnjost, budućnost; tri Mesečeve faze, itd. tri je „nebeski“ broj“, koji predstavlja dušu, kao što je četiri telo; oni skupa čine sedam i obrazuju svetu sedmicu." Dž. Kuper, Ilustrovana enciklopedija tradicionalnih simbola, Prosveta-Nolit, Beograd, 1986, str. 20.

8 „Nada; zgoda; otvaranje; prelaženje iz jednog stanja ili sveta u drugi; ulaz u novi život; inicijacija; skloniteljski vid Velike majke“ Dž. K. Kuper, nav. delo, str. 187. 
нови простор, иза врата сигурно постоји нови почетак. Скривена космогонија и почетак градње именовани су у вратима која су дефинисана. Она добијају различите атрибуте, чије значење ће имати важну улогу у генези настанка земаљских градова. Прва врата су од злата, друга од бисера, а трећа од скерлета, материје које представљају највише својство духовности и животодавну моћ Велике мајке (СМР 1970). Злато је повезано са мушким принципом, који долази одозго и који има функцију стварања. У самом чину настајања града $н и$ на небу ни на земљу догађају се две иницијације. У једној, вила жени сина, а свака женидба представља иницијацију у којој младу доводе у дом. Народни певач не каже ко је невеста, али се именовањем свадбе дефинише простор у којем се зачиње будући живот. На другим вратима вила удаје кћер. Како невеста мора да напусти свој дом успоставља се кретање у супротном правцу. Довођењем младе (женидбом сина) и одвођењем младе (удајом ћерке) успоставља се комуникација са неименованим просторима о којима народни певач не говори ништа.

У граду на облаку догађа се свети чин спајања мушког и женског принципа. Како градњи сваке грађевине мора да претходи приношење жртве, и у граду на облаку назире се жртва која на први поглед није видљива. Наиме, и у обреду прелаза (у овом случају свадба) могуће је наћи зачетак жртвовања. Занимљиво је посматрати шта би у овом случају у небеском граду могла бити скривена жртва. Ако се по правилима жртвеног обреда увек жртвују брат и сестра могуће је да у градњи чудесног града, у самом чину удаје и женидбе, вила жртвује сина и ћерку, односно жртвовани су брат и сестра. Тиме је обезбеђена стабилност града на облаку сакривена у симболици првих и других врата. Чудес- 
на, трећа врата, од скерлета на којима вила сама сједи погледује/Ђе се муна с громом игра/мила сестра са два брата/ а невеста с два девера (СНП, Вук 1969: 150) доносе разрешење тајне небеског града. Очигледно је да у њему доминира женски принцип, а увођење игре, асоцира на првобитно својство богова. Игром, која се догађа на плану неба (муна грома надиграла) и на плану земље (мила сестра оба брата/ а невјеста два ђевера) отварају се нове могућности у тумачењу песме и тајне града на грану од облака. Трећа врата доносе стабилност где вила сама сједи и погледује игру која се одвија у опозитном простору горе/доле. У песми се не конкретизује изглед града, али се кроз сватовску иницијацију на неки начин обезбеђује стабилност који, како наводи Миодраг Павловић, као да се (град) подизао да буде симболом будућих домова младенаца (Павловић 1993: 35). Проласком кроз иницијацију простор добија атрибуте светости а златна боја му даје категорију највише вредности.

У зависности од етнопсихолошке средине у којој је песма живела долазило је до извесне промене, па је и град на облаку, или под небесима, добијао другачије атрибуте. У неким срединама он ће задржати симболику троја врата и сватовског обреда, али ће се у неким варијантама, као у песмама са Косова и Метохије, на граду појавити и црква (Бела вила град градила/На сред град бела ирква (Дебељковић 1984: 47). Лаганом христијанизацијом град добија на сакралности. Црква постаје нови симбол, али песма не напушта своје првобитно значење, а то је обезбеђивање плодности које се огледа у победи и доминацији женског начела. Народни певач прибегао је и додавањем новог материјала од кога се саграђена врата а то је кремен врста апотропајона који симболизује плодност и има лустративну моћ којом се обезбеђује ритуално чишћење простора 
(Kuper 1986: 75). У каснијим варијантама град ће потпунио нестати и његове атрибуте преузеће црква, која се гради сама од себе. Полако нестаје и вила, и у песма са Косова и Метохије јасно се види у ком правцу је ишла демитологизација митолошке песме о зидању небеског града. Симболи врата која су од вредног материјала замењују се симболима из свакодневног живота који су били или део јуначке или сватовске иницијације.

Необичан небески град налазимо и у бајкама и у предању, где се простор небеског спушта на земљу, или је град замењен чардаком ни на небу ни на земљи. Оно што је заједничко за све грађевине које се граде на небеском простору (град, црква или чардак) то је да се налазе у простору који је негде између, тамо где се на чудесан начин спајају симболи неба и земље. То је предео где су настале прве сакралне грађевине које ће се спустити на земљу, али које ће на обрисима неба бити јасно дефинисане. Краљ Милутин гради Грачаницу на основу поруке коју је добио у сну, а то је петокуполна црква коју је угледао на облаку. ${ }^{9}$

У простору ни на небу ни на земљу град који гради вила у неким фолклорном жанровима, рецимо бајци,

9 „Краљ сутрадан устаде пре сунца и виде на небу красан и велик облак са пет кубета. Дозва одмах мајсторе, те стаде још тога пролећа градити цркву и сагради је до крова. На зиму, мајстори се разиђу а кад дође опет пролеће, мајстора нема да дођу. Поручивао им краљ и тражио их, али они не дођоше за три године а црква је све тако стајала недограђена. Кад дођоше треће године а краљ срдит нареди да се протомајстору скине глава. мајстор му се замоли и рече: Да сам дошао одмах, истина би црква била готова још прве године али не би трајала ни триста година, али ја нисам дошао три године те је слегао и темељ и зид, па кад ударим још и добре сводове, трајаће не триста година него, и име божије и у славу краљску, во веки века“. Владимир Бован, Народна књижевност Срба на Косову, народне приповетке, I, Јединство, Приштина, 1980, стр. 119. 
замењен је чардаком ни на небу, ни на земли. У бајци из Вукове збирке Чардак ни на небу ни на земли (СНП а, Вук 1969: 65) облак је унапред дефинисани простор у коме је настањен змај који уграби цареву ћерку. Путовање царевих синова, који траже уграбљену сестру, завршава се на чардаку који нити је на небу нити је на земљи (СНП а, Вук 1969: 65). Ако бисмо направили паралелу између града који гради вила и чардака, у којем обитава змај, уочавамо да и у једном и другом простору на облаку доминира женски принцип. Иако је у вилином граду, у игри, победу однела жена, на чардаку, где обитава змај, преко уграбљене девојке, уводи се и женско начело. Аналогију између града у песми и бајци налазимо и у вратима која су била носилац дешавања и тајних знања у оба жанра. Наиме, у песми доминирају троја врата. У бајци ће се врата трансформисати у тајне собе у којима су необични коњи украшени различитим материјалом (злато, сребро и драго камење). Појављивање троја врата у бајци, у којима су три девојке, имају неку аналогију са троја врата на облаку који гради вила. Појава златне боје, у бајци, и девојке која је сједила за златним ђерђебом и златном жицом везла (СНП Вук 1969 а: 66) указује на доминацију женског принципа и златне боје, као атрибута небеског. Ако је вила која гради активна, јер жени сина и удаје кћер, у бајци ће чардак ни на небу ни на земљи носити такође активан принцип јер је и у њему девојка, која везе златном жицом. И једна и друга као да се баве неким светим послом, загледане у стварање. Ако је град на облаку архаична представа стварања, онда ће жена (вила и девојка) добити важну улогу у том стварању, односно атрибут градитељке.

Можда ће нам у разрешавању тајне небеског града помоћи и једна лирска песма која гласи: Разгради се бела вила/ни на небу ни на земли/веће у том белом 
зраку/белом зраку трој облаку/у вили је чудно чудо/ Света ирква Исусова/и у иркви још чудније/Та Огьена, та Марија (Милојевић 1869: 16). У песми су сачувани обриси градње града који, као да се на неки начин разграђује. Сачуване су формуле ни на небу ни на замљу, вила која зида град, трој облак (замена за троја врата) али се уводи синтагма чудно чудо и Света ирква Исусова. У песми се види пут христијанизације, али је и у њој доминантан женски принцип, Огњена Марија. Она је сачувала оне атрибуте које је у митолошкој песми имала вила. Огњена Марија у овој песми обавља исто оно што је обављала девојка у бајци Чардак ни на небу ни на земльи. Она Везак везе ситно плете/Силном Ристу младом Богу/Ону златну алинииу/од сувога чистог злата/ Чистог злата тога огюа/Тога огња жестокога./Од сувога чистог сребра/Чистог сребра чисте срме (Милојевић 1869: 16). Песме о градњи небеског града ишле су у правцу лагане христијанизације, где долази до замене града црквом. Град са троја врата замениће трој облак, али ће се манифестација женског принципа показати присуством виле, ћерке коју удава, девојке коју уграби змај и одводи на облак, девојке које су у необичним собама на чардаку, али и позиционирању жене (девојке) која седи за ђерђефом и златном жищом везе (у бајци). Да је мотив зидања града на облаку доживео лагану трансформацију у правцу градње сакралног објекта, цркве, показују и горе наведени стихови у којима се уместо девојке која везе златном жицом појављује Огњена Марија. Активна улога жене у овим песмама је несумњива, али и присуство драгоцене материје попут злата, сребра, скерлета и срме. Све ово указује да је град представљао вредност, почетни облик онога што ће бити одраз градова који ће бити изграђени и на земљи. 
Тајну градње небеског града можда би требало потражити и у варијантама са других простора, да би се стекла целовита слика. У једној песми из Лике град граде бијеле виле где поново налазимо константну формулу да гради граде од троје врата. Златна врата су константна, док су обележја других и трећих врата променљива. У овој песми појављује се стих друга врата танка платна на којима онђе мајка ћер удаје (Беговић 1885: 2) што опет указује на доминацију жене, уз присуство босиљка на трећим вратима који, као апотропајон, има значајну улогу у теургичним радюама при жртви и молитви (Чајкановић б: 1994: 39). Христијанизацију чудесног града налазимо и у песмама са Косова и Метохије где су Трећа врата Христосова/У юу поју три анђела (Дебељковић 1984: 49). Да су трећа врата доживела потпуну христијанизацију потврђује и веровање на Косову и Метохији да се на Ускрс отварају рајска врата (Бован 1977: 66).

Песме о зидању града на облаку живеле су на ширем српском простору, не само у лирским песмама већ су транспоноване и у епску традицију (Пешикан Љуштановић 2009: 59-75). На основу грађе коју смо имали на увид показало се да генезу градње небеског града треба тражити у митолошким песмама у којима је из сфере небеске свадбе, у којој се уређује космос, град полако измештен у сферу поднебесја, односно облака. У процесу христијанизације град је био замењен црквом, сакралном грађевином, што наводи на закључак да је и градња града представљала сакрализацију простора. Симболи о којима је било речи (вила, врата, злато, скерлет, црква...) указују на комплексност овог мотива који је нашао место и у Јеванђеть, односно Откровену Јовановом, у којем настаје ново небо јер прво небо и прва земла прођоше (СП, 2010: 21, 1). Успостављају се 
ново небо и нова земља и Свети град, Јерусалим нови, где силази са неба од Бога, припремлен као невјеста украшена мужу својему (СП, 2010: 21, 2). И у Светом писму, у последњој глави, налазимо слику Светог града, Јерусалима, који је, аналогно ономе што је у небеском граду видео народни певач припремлен као невјеста украшена мужу својему, где невеста представља цркву, а женик Исуса Христа.

Можда би истраживање мотива небеског града у фолклористици требало проширити и на писану књижевност, посебно средњовековну, где би се бацило ново светло на утицај усмене и писане књижевности, где би се показала генеза религиозног архетипа, посебно у балканском и словенском контексту.

\section{ИЗВОРИ И ЛИТЕРАТУРА}

Беговић, Никола. Српске народне пјесме из Лике и Баније, које је сакупио и за штампу приредио Никола Беговић, књига прва, Загреб: Штампарија Ф. Фишера и др, 1885.

Бован, Владимир. Српске народне песме са Косова и Метохије. Приштина: Јединство, 1977.

Дебељковић, Дена. Српске народне умотворине са Косова и Метохије из рукописа Дене Дебелковића, книга прва, тирске и епске народне песме. Приштина: Академија наука и уметности Косова, 1984.

Милојевић, Милош С. Песме и обичаи укупног народа Србског, прва книга, обредне песме. Београд: Државна штампарија, 1869.

СНП. Стефановић Караџић, Вук. Српске народне пјесме, скупио их и на свијет издао Вук Стеф. Караиић. Книга прва, у којој су различне женске пјесме. Приредио Владан Недић. Београд: Просвета, 1969.

СНП. Стефановић Караџић, Вук. Српске народне приповијетке. Приредио Владан Недић. Београд: Просвета, 1969 a. 
Бандић, Душан. Народна религија Срба у 100 појмова. Београд: Нолит, 1991.

Елијаде, Мирча. Свето и пробано. Сремски Карловци - Нови Сад: Издавачка књижарница Зорана Стојановића, 2003. Јанковић, Ђ. Ненад. Астрономија у предағима, обичајима и умотворинама Срба. Београд: Српска академија наука, 1951.

Kuper, Dž. K. Ilustrovana enciklopedija tradicionalnih simbola, preveo Slobodan Djordjević, Beograd: Prosveta-Nolit, 1986.

Нојман, Ерих . Историјско порекло свести, Београд: Просвета, 1994.

Павловић, Миодраг. Огледи о народној и старој српској поезији. Београд: СКЗ, 1993.

Пешикан Љуштановић, Љиљана. „Вилински град у хајдучкој песми - од рефлекса древног мита до алегорије“, у Синхронијско и дијахронијско изучаване врста у српској књижевности. Нови Сад: Филозофски факултет, 2009.

СМ. Словенска митологија, енииклопедијски речник, Редактори Светлана Толстој, Љубинко Раденковић, Београд: Zepter book world, 2001.

СМР. Ш. Кулишић, П. Ж. Петровић, Н. Пантелић. Српски митолочки речник. Београд: Нолит, 1970.

СП. Свето писмо. Београд: Свети архијерејски синод Српске православне цркве, 2010.

Чајкановић, Веселин. Стара српска религија и митологија. Београд: СКЗ, БИГЗ, Просвета, Партенон М.А.М, 1994.

Чајкановић, Веселин. Речник српских народних вероваюа о биљкама, Београд: СКЗ, БИГЗ, Просвета, Партенон M.A.M, 19946. 
Valentina Pitulić

\section{THE HEAVENLY CITY IN THE SERBIAN ORAL TRADITION}

\section{Summary}

The paper is focused on the heavenly city, which is in the oral tradition of the Serbs most often established in the area under the sky, that is, on a branch of clouds. We shall demonstrate how the city, which is built by mythological creatures, have acquired a Christian character over time, in which case the church is being built on its own. The poems about building a city on a cloud ensure fertility. The presence of the female principle (fairy, girl, Fiery Mary) indicates the origin of the poem, which represents a kind of construction anthem. The presence of the heavenly city in prose genres also indicates its complexity, which requires a new reading aimed at following the genesis of the constructing the city on the cloud in the mirror of variants of different ethnopsychological communities.

Key Words: city, sky, cloud, fairy, girl, door, gold, church. 